\title{
Analyzing Factors Affecting the Use of Voluntary Disclosure Information using a Modified Theory of Reasoned Action: A Study in Indonesia
}

\author{
GUNAWAN WIBISONO* \\ Universitas Gadjah Mada \\ DEVIE DWI ARYANI PUTRI \\ Employee, PT Bank Rakyat Indonesia
}

\begin{abstract}
Voluntary disclosure information has been a research topic for a long time. However, very few tried to explain it from the investors' point of view. This study attempted to justify the use of voluntary disclosure information by using a modified Theory of Reasoned Action (TRA) model by adding perceived freedom of physical effort as a third behavior beliefs construct. By using SEM and path analysis, this study found that all three behavior beliefs constructs affect behavior intention to use voluntary disclosure information. Perceived usefulness and perceived freedom of physical effort have a direct effect on behavior intention in using voluntary disclosure information while perceived ease of use is having an indirect impact to behavior intention in using voluntary disclosure information through perceived usefulness. This study has opened a path to a new view of research in voluntary disclosure topic, which is the information-seeking behavior from the investors' point of view. Further study related to this new view can be done to further extend the TRA model in particular to voluntary disclosure information setting.
\end{abstract}

Keywords: voluntary disclosure, TRA, perceived usefulness, perceived ease of use, behavior intention

Intisari: Pengungkapan informasi sukarela telah menjadi topik penelitian untuk waktu yang lama. Namun, sangat sedikit yang mencoba menjelaskannya dari sudut pandang investor. Penelitian ini berusaha untuk membenarkan penggunaan informasi pengungkapan sukarela dengan menggunakan model Theory Reasoned Action (TRA) yang dimodifikasi dengan menambahkan kebebasan yang dirasakan dari usaha fisik sebagai konstruk keyakinan perilaku ketiga. Dengan menggunakan SEM dan analisis jalur, penelitian ini menemukan bahwa ketiga konstruk keyakinan perilaku mempengaruhi niat perilaku untuk menggunakan informasi pengungkapan sukarela. Dirasakan kegunaan dan kebebasan yang dirasakan dari upaya fisik memiliki efek langsung terhadap niat perilaku dalam menggunakan informasi pengungkapan sukarela sementara persepsi kemudahan penggunaan memiliki dampak tidak langsung dengan niat perilaku dalam menggunakan informasi pengungkapan sukarela melalui

*Corresponding author: gunawanw@ugm.ac.id 
kegunaan yang dirasakan. Studi ini telah membuka jalan untuk pandangan baru penelitian dalam topik pengungkapan sukarela, yang merupakan perilaku pencarian informasi dari sudut pandang investor. Studi lebih lanjut terkait dengan pandangan baru ini dapat dilakukan untuk lebih memperluas model TRA khususnya untuk pengaturan informasi pengungkapan sukarela.

Kata Kunci: pengungkapan sukarela, TRA, persepsi kegunaan, persepsi kemudahan penggunaan, niat perilaku

\section{Introduction}

Information disclosure has now become an essential issue in respect of the longterm prosperity of the Indonesian stock market and sustainable development of the Indonesian economy. Corporate disclosure plays an important role, which contributes positively to a country's sustainable economic development (Botosan, 1997; Bushman and Smith, 2003). Corporates make a considerable effort, so that disclosed information make a positive impact on the economy (Ioannou and Serafeim, 2017). Despite the attempt by corporates who spend a lot of money to provide the information, do they being used by investors? The purpose of this study is to investigate factors affecting the usage of the information, particularly the voluntarily disclosed information, regarding the investor's decision making. The investigation is conducted by questioning investors in using the voluntarily disclosed information provided by corporates on their annual reports to the investor's decision making by using the Theory of Reasoned Action (TRA).

Voluntary disclosure is defined as the information primarily outside the financial statements that are not explicitly required by accounting rules or standards (FASB, 2001). In general, people make an effort to find information to solve a problem or make a decision. Wilson (1999) provides a problem-solving model using information-seeking behavior and the searching process. The model represented research topics as a series of nested fields, with information behavior as the general area of investigation, information-seeking behavior as its sub-set, and information searching behavior as a further subset. The model combined information-seeking activities and problem-solving activities. 
Tao (2008) stated that by understanding the perceived the usefulness of information and factors affecting it will help us in understanding the reasons why users choose to use the information. This approach is the beliefs-attitude-behavior intention-actual behavior type of approach, which applied from the Theory of Reasoned Action (TRA) that aims to explain and predict human behavior. Fishbein first introduces this theory in 1967 and developed by Fishbein and Ajzen in 1975. The theory focuses on the cognitive process and assumes that human is a creature that has a reasonable thinking process in his behavior, which uses information around him systematically. In one of the TRA's extension, Technology Acceptance Model (TAM), Davis (1989) and Davis et al. (1989) found that attitude variable is not an appropriate predictor of behavior and the result showed that without attitude, TAM could better predict and explain the behavior of information users. Some other research (Venkatesh, 2000; Fathema and Sutton, 2013; Fathema et al., 2015) also found similar results after eliminating the attitude variable. This study will also remove the attitude variable and is using the beliefs-behavior intention-actual behavior type of approach. In TRA, beliefs are measured by perceived usefulness and perceived ease of use. We also adopted another measurement of beliefs from Tao (2008), which is the perceived freedom of physical effort.

This study aims to make a significant contribution to the existing literature, which focuses on the investor's perspective, rather than the corporate's. Previous studies (BenAmar \& McIlkenny, 2014; Cassar et al., 2015; Depoers et al., 2016; Ioannou and Serafeim, 2017) tried to explain the benefits of voluntary disclosure for the corporates, including in reducing the information asymmetry. Other studies actually tried looking at the stakeholders' point of view, and found that stakeholders have a huge influence on corporates in providing the voluntarily disclosed information (Qu et al., 2013), however there has been no study that tried to explain the investors' behavior in using the voluntary disclosed information and factors that affect their behavior. We hoped that this study would help both corporate and investors in understanding the reasons why voluntarily 
disclosed information is used in the decision-making process. Thus, will help corporate to allocate their resources better to provide more appropriate voluntary disclosed information to the investors.

The remainder of this paper is organized as follows. In the second section, we will discuss our theoretical background, followed by a review of relevant literature. We will then develop our hypothesis and outline our research methodology. Finally, we will discuss our findings and make concluding remarks.

\section{Theoretical Framework and Hypothesis Development}

\subsection{Annual Report and Voluntary Disclosure}

Weston et al. (1993) stated that annual report is a report that produced once a year by management for the stakeholders. The annual report consist of two information: (1) verbal section, which consists of management's opinion on corporate's past performance as well as prospects, and (2) annual financial statements, which include an income statement, balance sheet, owner's equity statement, and cash flow statement. Disclosure is not limited to the only financial statement but also the verbal section inside the annual report (FASB, 2001).

Meek et al. (1995) define voluntary disclosures as the disclosures made more than their requirements. They represent free choices of management to provide information for financial statement users that are deemed to be relevant in making decisions. Academic researchers classify voluntary disclosures into three types, namely, strategic information which includes general corporate information, corporate strategy, acquisition and disposals, research and development and prospects; and financial information, which provides segmental information, financial review, foreign currency information, stock price information, and non-financial information disclosure. This includes sections such as non-financial information about directors, employee information and social policy. (Meek et al., 1995; Eng and Mak, 2003).

Suwardjono (2005) states that both agency theory and signaling theory can be used to explain the need for voluntary disclosure. The difference in the amount of information between the agency and the principal can lead to information asymmetry. The gap is 
shown by information asymmetry thus leads to the existence of voluntary disclosure, which believed will be able to shorten the gap (Meek et al., 1995; Ben-Amar and McIlkenny, 2014; Qu et al., 2013). Management will also be interested in delivering information that can improve its credibility and success to give a signal to the market even though the information is not required (Meek et al., 1995; Depoers et al., 2016; Ioannou and Serafeim, 2017).

\subsection{Theory of Reasoned Action}

Theory of Reasoned Action (TRA) was first proposed by Fishbein (1967) and then refined, developed, and further tested by Fishbein and Ajzen (1975). TRA has been developed and based on the assumption that humans are generally rational and use the information available to them systematically. Humans tend to consider the consequences of their actions before they decide to do so. Ajzen and Fishbein (1980) states that the interest or intention of a person to perform a specific behavior will be done or not done the behavior. The underlying assumption is the same as the research that will be done by the author that investors in making decisions will go through a rational process.

Furthermore, they mention that the intention of performing or not performing certain behaviors is influenced by two essential determinants that are related to attitude (attitude towards behavior), and connected to social influences namely subjective norms. In expressing the impact of subjective norms and attitudes on the intention to perform the behavior or not, Ajzen uses beliefs. According to Ajzen and Fishbein (1980), attitude stems from beliefs about behavior, whereas subjective norms derive from normative beliefs. Schematically, the TRA is described as a schematic in Figure1.

\subsection{Previous Research in Indonesia}

A lot of research has been done to voluntary disclosure, particularly in Indonesia, but most are reviewing voluntary disclosure from the company's point of view, while 
research from investors has never been done before. So far, there has been no theoretical and empirical literature analyzing factors that may affect the voluntary disclosure interest of the investors. Several previous studies on voluntary disclosure among others are research on factors affecting the extent of voluntary disclosure on the annual report of companies listed on the Indonesian Stock Exchange conducted by Amalia (2005), the results suggest that the larger the size of the firm and the more shares publicly owned, the more voluntary information is disclosed in the annual report. Other research by Almilia (2008) on factors affecting voluntary disclosure of internet financial and sustainability reporting using a sample of 104 research companies provides evidence that firm size, corporate profitability, and majority ownership are the variables that determine the level of voluntary disclosure companies represented by the increase in Internet Financial and Sustainability Reporting (IFRS) index. Some other research found that company's audit committee and company's size affect the corporate social responsibility voluntary disclosure, in which will have a positive effect on future performance (Siregar and Bachtiar, 2010; Angelia and Suryaningsih, 2015).

Figure 1

Theory of Reasoned Action (Ajzen and Fihbein, 1980)

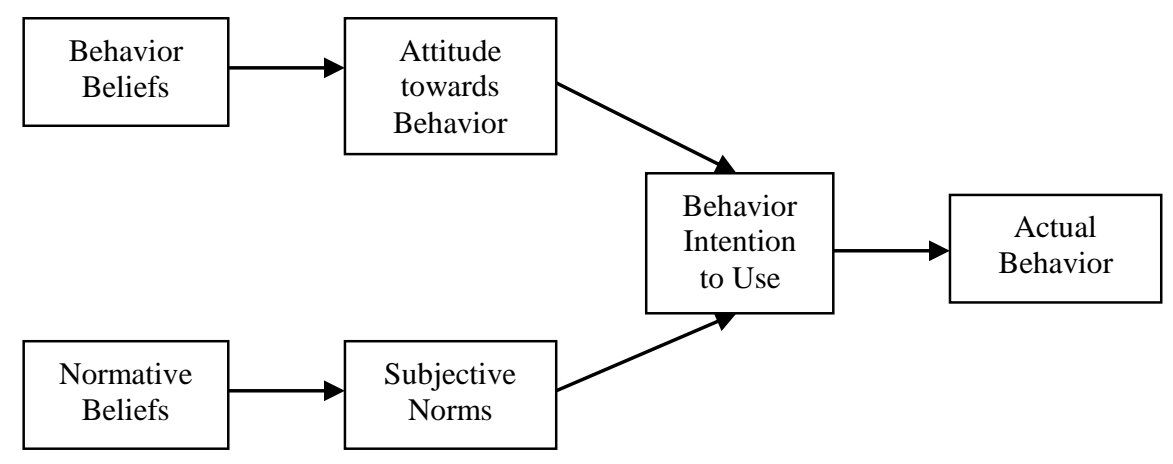

\subsection{Hypothesis Development}

Tao (2008) modified the TRA form to be more suitable and able to meet the objectives of the study. It eliminates attitude toward behavior based on previous 
research which has resulted in stronger results in assessing relationships and influences among variables. He also mentioned that normative beliefs and subjective norms do not affect the use of voluntary or non-obligatory information. The use of involuntary information disclosure by investors as the basis for making informed decisions is not mandatory, and it is purely from the perception of everyone in viewing the information whether it is useful or not in making investment decisions, so this research will also eliminate normative beliefs and subjective norms variable. The notion of each of the variables of the TRA either used or omitted will be explained below.

\subsubsection{Behavior Beliefs}

In the TRA (Fishbein and Ajzen, 1975), any behavioral belief (the perceived consequence of conducting a behavior) is multiplied by the evaluation of each consequence of the expectancy-value attitude model. Tao (2008) found that behavioral beliefs of information usage include (1) perceived usefulness, (2) perceived freedom of intellectual effort, and (3) perceived freedom of physical effort. While perceived usefulness is already aligned with TRA, he found that perceived freedom of intellectual effort is the same as perceived of ease of use and perceived freedom of physical effort is a new variable in predicting information usage. This study will also use perceived freedom of physical effort in addition to TRA's behavioral beliefs variables.

\subsubsection{Perceived Usefulness}

Perceived usefulness shows the advantage of using an information source. Information will be useful if the information can meet what the user searches for information in fulfilling a goal or make certain decisions. Davis (1989) defines perceived usefulness as the degree to which a person believes that using a particular system can improve the work performance of that person. When linked with information, perceived usefulness can be defined as the degree to which a person believes that using a particular source of information can improve his/her performance. 


\subsubsection{Perceived Ease of Use}

Perceived ease of use is defined as the degree to which a person believes that the use of information is easy and requires no great effort from the wearer. This concept includes the clarity of the purpose of the use of information to achieve a goal according to the wishes of the user (Davis, 1989). Adams et al. (1992) argue that perceived usefulness and perceived ease of use are important factors that influence the use of information that can be seen from a person's intent to use that information. The intensity of use and interaction between users with the system can also indicate ease of use. The more frequently systems are used to show that the system is better known, easier to operate and easier to use by its users (Venkatesh, 2000).

\subsubsection{Perceived Freedom of Physical Effort}

Nowadays there are so many choices of information sources, users can choose information from various sources, but this also leads to the occurrence of information explosion which then increases the difficulty for the user in finding information quickly and precisely. Perceived freedom of physical effort is defined as the degree to which information users do not require more effort such as surveys and investigations to obtain information from voluntary disclosure. This construct is first introduced byTao (2008) to explain behavior beliefs further.

\subsubsection{Attitude Toward Behavior}

Fishbein and Azjen (1975) mentioned that when a person establishes his belief about the consequences of performing a behavior (behavior), automatically and simultaneously the person will gain an attitude toward behavior. In TRA, attitude toward behavior predicts behavior intention. Intention reflects the choices one has made between performing or not conducting behavior, and this has been shaped through a process of considerable mental, conflict, and commitment considerations. Intention indicates a more stable mental state than the attitude of a person regarding performing a behavior. From this point of view, the intention is a better behavioral predictor of attitude when the intention has been established.

Also, Davis et al. (1989) suggested revising the TAM (Technology Acceptance Model) by eliminating the attitude and research variables demonstrated that this revised 
model is stronger for predicting and explaining user behavior information, based on three theoretical foundations, i.e., intention, perceived usefulness, and perceived ease of use. Many empirical studies have been conducted using this revised TAM and found that there is significant influence between behavior beliefs and behavior intention (Venkatesh. 2000; Fathema and Sutton, 2013; Fathema et al., 2015).

\subsubsection{Normative Beliefs and Subjective Norms}

Subjective norms are the variables used to measure normative beliefs. Based on the results of recent studies, no significant direct effect of normative beliefs to behavior intention was found (Davis, 1989; Davis et al., 1989; Venkatesh, 2000). According to Barki and Hartwick (1994), normative only affects certain situations. Venkatesh and Davis (2000) also found that subjective norms have a positive direct effect on the intention to use information that is required, but not for voluntary information. Based on this, this study will not use normative beliefs and subjective norms because the use of information in voluntary disclosure is not mandatory but is a voluntary choice for investors.

\subsubsection{Behavior Intention to Use}

According to the TRA (Ajzen and Fishbein, 1980), a person's behavior to use information or not, is determined by the interest or intention of a person to perform a behavior. Meanwhile, according to TAM (Davis., 1989; Davis et al., 1989), one's intention to use a system is affected by perceived ease of use and perceived usefulness.

\subsubsection{Actual Use Behavior}

TRA (Ajzen and Fishbein, 1980) uses behavior intention to predict actual usage behavior. Actual usage behavior is defined as the actual usage of the voluntary disclosure information in making an investment decision. It shows how intense and frequent the actual usage of the information. 


\subsubsection{The Effect of Perceived Usefulness, Perceived Ease of Use, and Perceived}

Freedom of Physical Effort on the Behavior Intention to Use Voluntary

\section{Disclosure Information}

This study tries to examine whether the three behavioral beliefs (perceived usefulness, perceived ease of use, and perceived freedom of physical effort) influence investor interest (intention) in using voluntary disclosure information. Perceived usefulness is a benefit one beliefs can be obtained when he uses the voluntary disclosure. While interest (intention) is a tendency of someone to use or not to use the voluntary disclosure. If voluntary disclosure is believed to have benefits for investors in making decisions, then it will affect the interest of investors to use voluntary disclosure in the decision-making process. As Davis (1989) points out, "intention will be formed based on performance considerations rather than simply on personal likes or dislikes concerning performing a behavior". Previous research (Davis et al., 1989; Venkatesh, 2000; Venkatesh and Davis, 2000) has shown that perceived usefulness has a positive and significant effect on the interest of using information. Perceived usefulness is the second most crucial determinant of three behavioral intention constructs.

H1a. Perceived usefulness positively affects behavior Intention to use voluntary disclosure information

In previous studies, there have been inconsistent discoveries regarding the effect of perceived ease of use on behavior intention. Some studies have found that perceived ease of use has a direct effect on behavioral intention but does not have the most significant impact as perceived usefulness does, while some others conclude that the effect of perceived ease of use is too weak to directly affect behavior intention (Davis et al., 1989; Chau and Hu, 2002; Fathema and Sutton, 2013).

Although previous research on perceived ease of use has no significant direct effect on behavior intention, Davis et al. (1989) state that perceived ease of use has been repeatedly identified as an important issue affecting the process of receiving information by users. They found that perceived ease of use affects perceived usefulness, and both perceived usefulness and perceived ease of use determine a person's attitude in using information. This attitude determines a person's behavior intention in using information. 
H1b. Perceived ease of use positively affect behavior Intention to use voluntary disclosure information

Perceived free of physical effort is a new construct developed by Tao (2008), his research shows that perceived free of physical effort has the strongest direct influence on behavior intention compared to the other two behavioral beliefs (perceived usefulness and perceived ease of use). The less effort it takes to get information, the more likely it is for someone to use that information. He also explained that when a learner considers which information will be selected and used to accomplish their task, free of physical effort is the first factor in their consideration, followed by usefulness and ease of use.

H1c. Perceived freedom of physical effort positively affect behavior Intention to use voluntary disclosure information.

\subsubsection{The Effect of Perceived Usefulness to Actual Use of Voluntary Disclosure}

\section{Information}

Previous studies (Davis, 1989; Davis et al., 1989; Fathema and Sutton, 2013) found that two behavioral beliefs (perceived usefulness and perceived ease of use) directly and or indirectly influence intention also affect actual usage. The present invention provides conclusions that can be applied by companies to intervene in providing voluntary disclosure information so that the actual use by information users can be improved.

H2a. Perceived Usefulness has a positive and direct effect on the actual use of voluntary disclosure information

2.4.11. The Effect of Behavior Intention to Use Voluntary Disclosure Information to Actual Use of Voluntary Disclosure Information

Davis (1989) with his TAM found that behavior intention to use technology is directly related to actual usage of the technology. His founding is aligned with TRA proposed by Fishbein and Ajzen (1975) that states behavior intention can be used to 
predict actual behavior. Other studies also proved similar findings at different research settings (Venkatesh, 2000; Venkatesh and Davis, 2000; Fathema and Sutton, 2013).

H2b. Behavior intention to use voluntary disclosure information positively affect the actual use of voluntary disclosure information

\subsubsection{The Effect of Perceived Ease of Use to Perceived Usefulness}

The more a system is easier to use, the more using it can increase job performance, which means that the lesser the effort in using the system, the more effective and efficient a job can be made (Davis et al., 1989; Venkatesh and Davis, 2000). This can also be applied to information usage. Tao (2008) also states that perceived ease of use will affect perceived usefulness. In other words, the easier it is for the user to interact with voluntary disclosure information, the more likely it is that the user will find the information useful and intend to use it again.

H3. Perceived ease of use positively affects perceived usefulness

From the above explanation, the research model based on TRA that has been modified and adjusted for research use of information on voluntary disclosure for investment decision making by users is proposed as follows:

Figure 2

Modified TRA Research Model

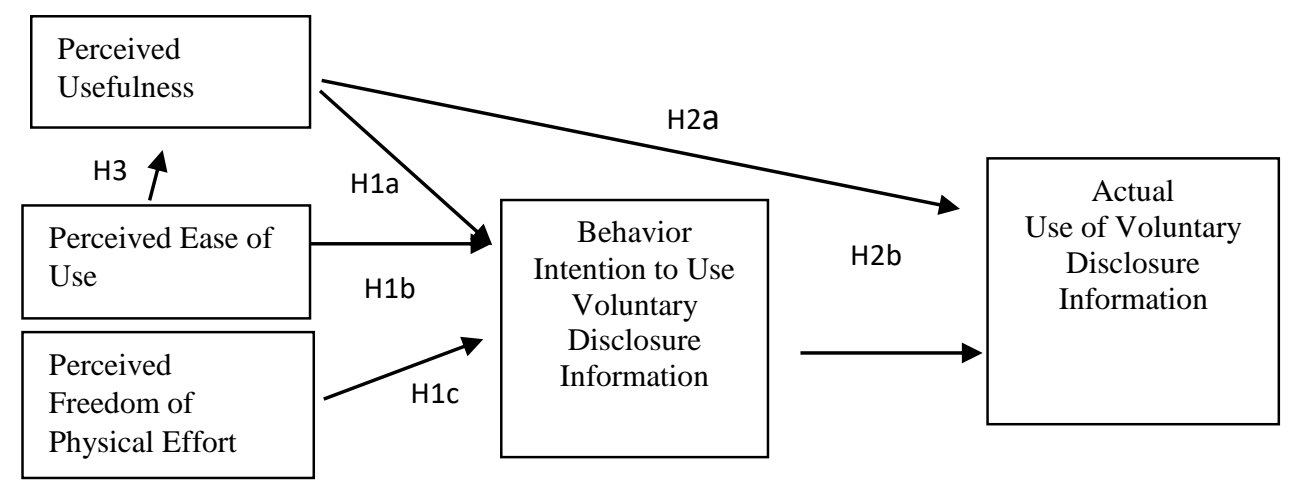




\section{Research Method}

Hypothesis testing is done with path analysis and structural equation modeling (SEM). SEM is a multivariate statistical technique that combines and integrates multiple regression. Data analysis techniques using SEM is done to explain thoroughly the relationship between variables that exist in the study. SEM is used not to design theory, but rather to examine and justify a model. Therefore, the primary requirement of using SEM is to construct a hypothetical model consisting of a structural model and a measurement model in the form of a path diagram based on the justification of theory. Multiple regression and path analysis each have only one indicator whereas SEM can simultaneously estimate all path coefficients and test the significance of each causal path, and allow to evaluate overall model performance by checking all goodness of fit hypothetical models (Bagozzi, 1981).

According to Bryne (2001, p. 7), SEM can be used to test proposed models, in which there are strictly confirmatory, alternative models, and generating models. Alternate models and generating models are more frequently applied than strictly confirmatory. In the alternative model, the researcher proposes several alternative models and tests the goodness of fit of each alternative model for a set of data and selects one of the best models representing the sample data. Alternate models can contain different variables or different causal paths between the same variables.

\subsection{Data Sample and Size}

This study is using a nonprobability sampling method in the form of purposive sampling. Purposive sampling is a non-random sampling design where the required information is obtained from specific targets of a group of people on a rational basis (Hartono, 2004, p. 79). Purposive sampling is done by taking samples from the population based on specific criteria. The established criteria for samples are office employees who have an understanding of voluntary disclosure information. The criteria were selected due to office employees can represent investors, in which they can 
generate income that can be used to invest. The employees also need to understand voluntary disclosure information so that they can make their decision regarding the information. Other than that, the criteria aim to increase the belief that respondents understand each question posed in the questionnaire so that the objectives of this study can be achieved. Also, they can also reduce the bias of the data generated.

The sample size to be met based on the maximum likelihood estimation (MLE) is at least 100 samples. When the sample is raised above the value of 100 MLE methods increases its sensitivity to detect differences between data. Once the sample becomes very large (above 400), then the MLE method becomes very sensitive and always produces a significant difference so that the size of Goodness of Fit becomes unreliable. This study received feedback from 102 respondents, with a majority of males and at the age between 25 to 27 years old, which described in the followings:

Table 1:

Sample Data by Sex Demography

\begin{tabular}{|l|l|l|l|}
\hline Sex & Total & & Percentage \\
\hline Male & 77 & & $75,49 \%$ \\
\hline Female & 25 & & $24,51 \%$ \\
\hline Total Respondents & 102 & & $100 \%$ \\
\hline
\end{tabular}

Table 2:

Sample Data by Age Demography

\begin{tabular}{|l|l|l|}
\hline Age & Total & Percentage \\
\hline $22-24$ & 31 & $30,39 \%$ \\
\hline $25-27$ & 56 & $54,90 \%$ \\
\hline $28-30$ & 15 & $14,71 \%$ \\
\hline Total & 102 & $100 \%$ \\
\hline
\end{tabular}

\subsection{Data Measurement and Pilot Study}

A survey technique is conducted by providing questions regarding information that might be useful for investment decisions. The questions are arranged in questionnaires using Likert scale model. The questionnaires used in this study consisted of two major 
groups: (1) general questions including sex, age, occupation, and experience using information in the annual report, (2) specific questions consisting of the variables illustrated in this study. The scale used is a Likert scale with five choices. Choices provided include strongly disagree (SD), disagree (D), neutral $(\mathrm{N})$, agree $(\mathrm{A})$, and strongly agree (SA). A pilot study is conducted to 33 purposely selected samples to measure the validity and reliability of measurement questions. The perceived usefulness construct is measured by five questions, coded USE 1 until USE 5. The pilot study shows that item USE 4 is not valid so it will not be used in this study. Four measurements coded EOU 1 to EOU 4 are used to measure the perceived ease of use construct, and under the pilot study, EOU 4 is dropped. The perceived freedom of physical effort construct is measured by four questions, behavior intention to use voluntary disclosure information is measured by three questions, and actual use of voluntary disclosure information is measured by two questions, each coded FPF1 to FPF 4, BI 1 to BI 3, and AU 1 and AU2, respectively. The pilot study shows that all remaining measurement items are valid and reliable.

\section{Research Findings}

The data were first analyzed by using Pearson product-moment for validity testing and Cronbach's alpha value for reliability testing. The result of both testings is shown in Table 3 and Table 4, respectively. The range for Pearson correlation is in between 0.511-0.879, and all correlation probability is below 0.05 , indicating that all data measured by item measurement are valid. The Cronbach's alpha value for each construct is all above the minimum threshold of 0.6 , which means that all data measured using the measurement items are reliable.

At the 0.05 significance level, the normality requirement is achieved when the skewness value and kurtosis value of the data used are smaller than \pm 1.96 . The result of data normality calculation shows that skewness value and whole construct kurtosis have a value below $\pm 1,96$ indicating that data distribution is considered normal. The 
dalanquin value of $\mathrm{d}$-squared for the $5 \%$ significance level with the number of indicator variables used $(16,0005)$ is 26.296 (based on the distribution table $\left.\chi^{2}\right)$. The greatest dalanqual dalanquin value in this study was 35,383 . These results indicate that there are data outliers. Data outliers will not be omitted in this study because it describes the actual state of respondents at the time of research.

Table 3

Validity Testing Using Pearson Product Moment

\begin{tabular}{|c|c|c|c|}
\hline $\begin{array}{c}\text { Measurement } \\
\text { Items }\end{array}$ & Pearson Correlation & $\begin{array}{c}\text { Correlation Probability } \\
\text { [sig.(2-tailed)] }\end{array}$ & Result \\
\hline USE 1 & 0.629 & 0.000 & Valid \\
\hline USE 2 & 0.825 & 0.000 & Valid \\
\hline USE 3 & 0.610 & 0.000 & Valid \\
\hline USE 5 & 0.646 & 0.000 & Valid \\
\hline EOU 1 & 0.681 & 0.000 & Valid \\
\hline EOU 2 & 0.637 & 0.000 & Valid \\
\hline EOU 3 & 0.623 & 0.000 & Valid \\
\hline FPF 1 & 0.539 & 0.000 & Valid \\
\hline FPF 2 & 0.511 & 0.000 & Valid \\
\hline FPF 3 & 0.595 & 0.000 & Valid \\
\hline FPF 4 & 0.551 & 0.000 & Valid \\
\hline BI 1 & 0.867 & 0.000 & Valid \\
\hline BI 2 & 0.829 & 0.000 & Valid \\
\hline BI 3 & 0.828 & 0.000 & Valid \\
\hline AU 1 & 0.879 & 0.000 & 0.000 \\
\hline AU 2 & 0.791 & & \\
\hline
\end{tabular}

Table 4

Reliability Testing Using Cronbach's Alpha

\begin{tabular}{|l|l|l|}
\hline Measurement Items & Cronbach's Alpha & Result \\
\hline USE & 0,808 & Reliable \\
\hline EOU & 0.847 & Reliable \\
\hline FPF & 0,801 & Reliable \\
\hline BI & 0,917 & Reliable \\
\hline AU & 0,879 & Reliable \\
\hline
\end{tabular}


The goodness fit of the model in this study is measured by using path analysis, and the result shows that overall, the research model proposed was appropriate to be used in this study. All goodness of fit index value shows favorable results except for probability value, which resulted at 0.007 , still below the minimum threshold of 0.05 . The CMIN/DF, TLI, CFI, and RMSEA value show that the proposed model is fit while ChiSquare, GFI and AGFI index value indicates that the model is adequately fit. These results can be seen in Table 5 and Figure 3.

Table 5

Goodness of Fit Path Analysis Result

\begin{tabular}{|l|l|l|l|}
\hline $\begin{array}{l}\text { The goodness of Fit } \\
\text { Index }\end{array}$ & Output Value & Cut of Value & Result \\
\hline$X^{2}$ Chi Square & 136,192 & Minimum & Adequate fit \\
probability & 0,007 & $\geq 0,05$ & Less fit \\
CMIN/DF & 1,390 & $\leq 2,00$ & Fit \\
GFI & 0,870 & $\geq 0,90$ & Adequate fit \\
AGFI & 0,820 & $\geq 0,90$ & Adequate fit \\
TLI & 0,955 & $\geq 0,95$ & Fit \\
CFI & 0,963 & $\geq 0,95$ & Fit \\
RMSEA & 0,062 & $\leq 0,08$ & Fit \\
\hline
\end{tabular}

The regression analysis shows that all hypotheses are proven except for $\mathrm{H} 1 \mathrm{~b}$, which has Continuum Regression (CR) value of 0.776 and probability level of 0.438 , both were not within the threshold value. H1a, H1c, H2a, H2b, and $\mathrm{H} 3$ each has $\mathrm{CR}$ value of $5.694,3.023,2.056,3.437$, and 5.387 respectively, which all show above the threshold level of \pm 1.984 . The probability level of those hypotheses was also found at a level below 0.05 , hence out of six hypothesis, five were proven. The detailed analysis result is shown in Table 6. 
Figure 3.

Path Analysis Result (in the diagram)

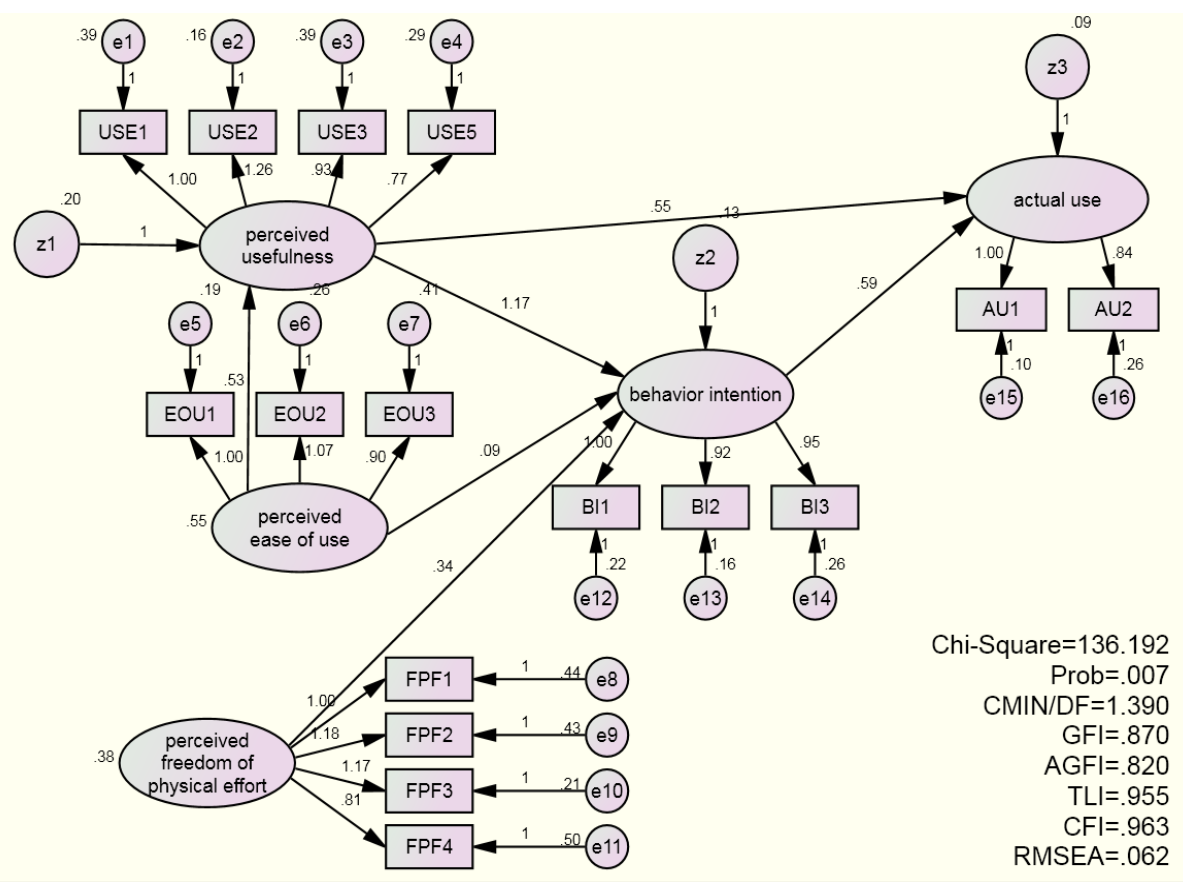

Table 6

Hypothesis Testing Results

\begin{tabular}{|c|c|c|c|c|c|c|c|c|}
\hline & & & & Estimate & S.E. & C.R. & $\mathrm{P}$ & \\
\hline H1a & $\begin{array}{l}\text { Behavior } \\
\text { Intention }\end{array}$ & $<---$ & $\begin{array}{l}\text { Perceived } \\
\text { Usefulness }\end{array}$ & 1.174 & .206 & 5.694 & $* * *$ & Proven \\
\hline H1b & $\begin{array}{l}\text { Behavior } \\
\text { Intention }\end{array}$ & $<---$ & $\begin{array}{l}\text { Perceived Ease of } \\
\text { Use }\end{array}$ & .094 & .122 & .776 & .438 & $\begin{array}{l}\text { Not } \\
\text { Proven }\end{array}$ \\
\hline $\mathrm{H} 1 \mathrm{c}$ & $\begin{array}{l}\text { Behavior } \\
\text { Intention }\end{array}$ & $<---$ & $\begin{array}{l}\text { Perceived } \\
\text { Freedom of } \\
\text { Physical Effort }\end{array}$ & .340 & .112 & 3.023 & .003 & Proven \\
\hline $\mathrm{H} 2 \mathrm{a}$ & Actual Use & $<--$ & $\begin{array}{l}\text { Perceived } \\
\text { Usefulness }\end{array}$ & .551 & .268 & 2.056 & .040 & Proven \\
\hline $\mathrm{H} 2 \mathrm{~b}$ & Actual Use & $<---$ & $\begin{array}{l}\text { Behavior } \\
\text { Intention }\end{array}$ & .587 & .171 & 3.437 & $* * *$ & Proven \\
\hline H3 & $\begin{array}{l}\text { Perceived } \\
\text { Usefulness }\end{array}$ & $<--$ & $\begin{array}{l}\text { Perceived Ease of } \\
\text { Use }\end{array}$ & .534 & .099 & 5.387 & $* * *$ & Proven \\
\hline & & & & & & & & \\
\hline
\end{tabular}




\section{Conclusions, Limitations, and Implications}

Perceived usefulness is proven once again as the strongest behavior beliefs construct among the other two, as shown by its standardized coefficient value of 1.174 , capable of affecting behavior intention at $117.4 \%$. This result is consistent to previous studies, both for behavior beliefs in using information technology (Davis et al., 1989; Venkatesh and Davis, 2000) and behavior beliefs in using information (Tao, 2008). Perceived freedom of physical effort has also proven to have a significant effect on behavioral intention. This means that easy access and convenience can directly affect the decision to use voluntary disclosure information by investors.

Perceived ease of use has always been having conflicting results in similar studies, and some found that the effect of perceived ease of use to behavior intention is too weak (Davis et al., 1989; Chau and Hu, 2002). In this study, perceived ease of use has not been proven to have a significant effect on behavioral intention. The result is still consistent with a similar study conducted by Tao (2008). Most of the respondents have a background in business and were very familiar with using information on financial statements, including voluntarily disclosed information. This means that the respondents have adequate experience in using the voluntary disclosure information. Hence they did not care whether the information is easy to use or not since they were already familiar with them. This reason is consistent to what Davis et al. (1989) have found where the direct effect of perceived ease of use to behavior intention will be weaker over time as users are familiar with the information technology being used until the direct effect diminished and it will indirectly affect behavior intention through perceived usefulness. This study also found that perceived ease of use is having a significant impact on perceived usefulness. In conclusion, the three behavior beliefs constructs can affect behavior intention to use voluntary disclosure information, albeit the perceived ease of use only has an indirect effect through perceived usefulness. 
This study found a strong relationship between perceived usefulness and actual use of voluntary disclosure information, which is consistent with previous studies (Davis et al., 1989; Venkatesh and Davis, 2000; Tao, 2008). This study also found that behavior intention also has a significant effect on the actual use of voluntary disclosure information, which is consistent with findings from previous studies (Ajzen and Fishbein, 1980; Alsamydal et al., 2015; Fathema et al., 2015). In conclusion, the more office employee perceived voluntary disclosure information to be able to increase their productivity and performance in investing, and the more effective their investment decisions become, the more useful they would think that voluntary disclosure information in their investment decision, the more likely they will use the voluntary disclosure information.

This study is one of the first studies on voluntary disclosure information that is viewed from the investor's point of view. This will give companies a different perspective in preparing their financial statements. Investors view voluntary disclosure information as useful in their investment decision making process. This means that companies can start giving more voluntary disclosure information to the investor since most of them will be used in their decision making, in other words, voluntary disclosure information is essential to investors.

Data outliers exist in this study and may or may not affect the results. If it affects the result, it may indicate some measurement errors in this study. Other possible limitations in this study include the criteria for the respondents, in which all respondents should know about voluntary disclosure information, and it will increase the likelihood of the familiarities on voluntary disclosure information. This may affect the findings of the second hypothesis.

Theoretically speaking, this study provides more supporting evidence to TRA and its extension models. This study also proven that perceived freedom from physical effort directly affect behavior intention. The construct is first introduced by Tao (2008) and based on this study's findings, and the construct can be used in a similar setting, which is on voluntary disclosure information. This study also creates a new view for a researcher to look at the investors' point of view on voluntary disclosure information. 
Future research can utilize other information-seeking behavior models in analyzing the use of voluntary disclosure information. Further research can also be done to find prove that perceived ease of use can also indirectly affect behavior intention through perceived freedom of physical effort under the notion that the more accessible information is understood then, the less effort needed in finding it, hence the more effective that information can be used.

\section{References}

Adams, D. A., Nelson, R. R., \& Todd, P. A. (1992). Perceived Usefulness, Ease of Use, and Usage of Information Technology: A Replication. MIS Quarterly, 16(2), 227-247.

Ajzen, I., \& Fishbein, M. (1980). Understanding attitudes and predicting social behavior. Englewood Cliffs, NJ: Prentice-Hall.

Almilia, L. S. (2008). Factors Affecting the Voluntary Disclosure of "Internet Financial and Sustainability Reporting". Journal of Accounting and Auditing Indonesia, 12(2).

Al-Razeen, A., \& Karbhari, Y. (2004). Interaction between Compulsory and Voluntary Disclosure in Saudi Arabian Corporate Annual Reports. Managerial Auditing Journal, 19, 351-360.

Alsamydal, M., Alnaimi, H., \& Dajani, D. (2015). Using Fishbein's Model to Measure Individual's Attitude Toward Electronic Communication Means. International Journal of Sales and Marketing Management Research and Development, 5(2), 1-18.

Amalia, D. (2005). Factors Affecting the Extent of Voluntary Disclosure on the Company's Annual Report on the Jakarta Stock Exchange. Jurnal Akuntansi Pemerintah, 1(2).

Angelia, D., \& Suryaningsih, R. (2015). The Effect of Environmental Performance And Corporate Social Responsibility Disclosure Towards Financial Performance (Case Study to Manufacture, Infrastructure, And Service Companies That Listed At Indonesia Stock Exchange). Procedia - Social and Behavioral Sciences, 211, 348-355.

Bagozzi, R. P. (1981). Causal Modelling: A General Method for Developing and Testing Theories in Consumer Behavior. Advances in Consumer Research, 8, 195-202.

Barki, H., \& Hartwick, J. (1994). Measuring User Participation, User Involvement, and User Attitude. MIS Quarterly, 18(1), 59-82.

Ben-Amar, W., \& McIlkenny, P. (2014). Board Effectiveness and the Voluntary Disclosure of Climate Change Information. Business Strategy and The Environment, 24(8), 704-719. 
Botosan, C. A. (1997, July). Disclosure Level and the Cost of Equity Capital. The Accounting Review, 72(3), 323-349.

Bryne, B. (2001). Structural Equation Modelling with AMOS: Basic Concepts, Applications, and Programming. London: Lawrence Erlbaum Associates.

Bushman, R. M., \& Smith, A. J. (2003, April). Transparency, Financial Accounting Information, and Corporate Governance. Economic Policy Review, 9(1), 65-87.

Cassar, G., Ittner, C. D., \& Cavalluzzo, K. S. (2015). Alternative information sources and information asymmetry reduction: Evidence from small business debt. Journal of Accounting and Economics, 59(2-3), 242-263.

Chau, P., \& Hu, P. (2002). Information Technology Acceptance by Individual Professionals: A Model of Comparison Approach. Decision Sciences, 32(4), 699-719.

Culnan, M. (1985). The Dimensions of Perceived Accessibility to Information: Implications for the Delivery of Information and Services. Journal of the American Society of Information Science, 36(5), 302-308.

Davis, F. D. (1989). Perceived usefulness, perceived ease of use, and user acceptance of information technology. MIS Quarterly, 13(3), 319-340.

Davis, F. D., Bagozzi, R. P., \& Warshaw, P. R. (1989). User acceptance of computer technology: A comparison of two theoretical models. Management Science, 35, 9821003.

Depoers, F., Jeanjean, T., \& Jérôme, T. (2016). Voluntary Disclosure of Greenhouse Gas Emissions: Contrasting the Carbon Disclosure Project and Corporate Reports. Journal of Business Ethics, 134(3), 445-461.

Eng, L. L., \& Mak, Y. T. (2003). Corporate governance and voluntary disclosure. Journal of Accounting and Public Policy, 22(4), 325-345.

FASB. (2001). Insights into Enhancing Voluntary Disclosures. Retrieved from http://www.fasb.org/brrp/brrp2.shtml

Fathema, N., \& Sutton, K. (2013). Factors influencing faculty members' Learning Management Systems adoption behavior: An analysis using the Technology Acceptance Model.

International Journal of Trends in Economics Management \& Technology, II(vi), 20-28.

Fathema, N., Shannon, D., \& Ross, M. (2015). Expanding the Technology Acceptance Model (TAM) to examine faculty use of Learning Management Systems (LMS). Journal of Online Learning and Teaching, 11(2), 210-233.

Fishbein, M. (1967). A behavior theory approach to the relations between beliefs about an object and attitude toward the object. New York: Wiley.

Fishbein, M., \& Ajzen, I. (1975). Belief, Attitude, Intention, and Behavior: An Introduction to Theory and Research. Reading, MA: Addison- Wesley. Retrieved from http://people.umass.edu/aizen/f\&a1975.html 
Gray, S. J., \& B, R. C. (1989). Voluntary Information Disclosure and the British Multinationals: Corporate Perceptions of Costs and Benefits. In A. G. Hopwood, International Pressures for Accounting Change. Hemel-Hempstead: Prentice Hall International.

Hartono, J. (2004). Business Research Method: Misguided and Experiences. Yogyakarta: BPFE.

Ioannou, I., \& Serafeim, G. (2017). The Consequences of Mandatory Corporate Sustainability Reporting. Harvard Business School.

Komalasari, Puput, T., \& Baridwan, Z. (2001). Information Asymmetry and Cost of Equity Capital. Indonesian Journal of Accounting Research, 4(1), 64-81.

Mardiyah, A. A. (2002). Influence of Asymmetry and Disclosure Information to Cost of Capital. Indonesian Journal of Accounting Research, 5(2), 229-256.

Meek, G. K., Roberts, C. B., \& Gray, S. J. (1995). Factors Influencing Voluntary Annual Report Disclosures By U.S., U.K. and Continental European Multinational Corporations. Journal of International Business Studies, 555-572.

Qu, W., Leung, P., \& Cooper, B. (2013). A study of voluntary disclosure of listed Chinese firms - a stakeholder persp Figure 4: Path Analysis Result (in the diagram)

ective. Managerial Auditing Journal, 28(3), 261-294.

Siregar, S. V., \& Bachtiar, Y. (2010). Corporate social reporting: empirical evidence from the Indonesia Stock Exchange. International Journal of Islamic and Middle Eastern Finance and Managemen, 3(3), 241-252.

Suwardjono. (2005). Teori Akuntansi: Perekayasaan Pelaporan Keuangan (3rd ed.). Yogyakarta: BPFE Yogyakarta.

Tao, D. (2008). Using Theory Of Reasoned Action (TRA) In Understanding Selection And Use Of Information Resources: An Information Resource Selection And Use Model. Columbia: University of Missouri.

Venkatesh, V. (2000). Determinants of Perceived Ease of Use: Integrating control, intrinsic motivation, an Fig Figure 3: Path Analysis Result (in the diagram)ure 5: Path Analysis Result (in the diagram)

d emotion into the Technology Acceptance Model. Information Systems Research, 11(4), 342365.

Venkatesh, V., \& Davis, F. D. (2000). A Theoretical Extension of the Technology Acceptance Model: Four Longitudinal Field Studies. Management Science, 46(2), 186-204. 
The Indonesian Journal of Accounting Research - May, Vol. 21, No.2, 2018

Weston, J. F., Brigham, E. F., \& Aberwald, D. A. (1993). Essentials of Managerial Finance. Portland: Dryden Press.

Wilson, T. (1999). Models in information behavior research. Journal of Documentation, 55(3), 249-270. 